\title{
VARIAÇÕES MORFOLÓGICAS DE EMBRIÕES SOMÁTICOS OBTIDOS A PARTIR DE INFLORESCÊNCIAS DE BANANEIRA
}

\author{
Silvia Balbão Filippi ${ }^{1,4}$; Beatriz Appezzato-da-Gloria²; Adriana Pinheiro Martinelli Rodriguez ${ }^{3 *}$ \\ ${ }^{1}$ Pós-Graduanda em Fisiologia e Bioquímica de Plantas - USP/ESALQ. \\ ${ }_{3}^{2}$ Depto. de Ciências Biológicas - USP/ESALQ, C.P. 9 - CEP: 13418-970 - Piracicaba, SP. \\ ${ }^{3}$ Lab. de Biotecnologia Vegetal - USP/CENA, C.P. 96 - CEP: 13400-970 - Piracicaba, SP. \\ ${ }^{4}$ Bolsista CNPq. \\ *Autor correspondente <adriana@cena.usp.br>
}

RESUMO: A embriogênese somática pode ser uma alternativa para o melhoramento de espécies vegetais, quando associada à transformação genética. A regeneração de plântulas a partir de embriões somáticos é dependente de vários fatores, entre eles, a qualidade do embrião somático. Neste trabalho embriões somáticos com diferentes características morfológicas são descritos. Embriogênese somática de bananeira, cv. Grand Nain e Nanicão Jangada foi induzida a partir de inflorescências funcionalmente masculinas, em meio de indução (MI) seguido de subcultivo em meio de germinação (MG), em ausência de luz. A presença de luz na indução, não favoreceu a resposta embriogênica. Em ausência de luz, os explantes da cv. Nanicão Jangada, durante os seis meses de cultivo, sofreram diversas alterações, como a formação de calos embriogênicos e não embriogênicos, formação de embriões somáticos, continuidade no desenvolvimento do botão floral ou oxidação do explante. A freqüência de resposta embriogênica foi baixa, com apenas $6 \%$ dos explantes formando embriões somáticos e $23 \%$ com formação de calos embriogênicos. O acompanhamento histológico e morfológico das alterações ocorridas nos explantes permitiu a identificação de embriões somáticos com características morfológicas distintas: com maior freqüência observou-se um tipo de embrião com morfologia semelhante ao embrião zigótico de Musa acuminata; em menor freqüência desenvolveram-se embriões somáticos semelhantes a embriões zigóticos de outras monocotiledôneas, indicando que em um único protocolo de embriogênese somática, é possível ocorrer a formação de diferentes padrões morfológicos de embriões somáticos.

Palavras-chave: Musa spp., embriogênese somática, cultura de tecidos, histologia, morfologia

\section{MORPHOLOGICAL VARIATION OF SOMATIC EMBRYOS OBTAINED FROM BANANA INFLORESCENCES}

\begin{abstract}
Somatic embryogenesis is an alternative for genetic breeding of plant species when associated to genetic transformation techniques. Regeneration of plantlets from somatic embryos relies on somatic embryo quality, among other factors. In this work, banana somatic embryos with different morphological characteristics are described. Banana somatic embryogenesis was obtained from functional male inflorescences in induction medium (MI) followed by subculture to germination medium MG, in the absence of light. Induction under a 16$\mathrm{h}$ photoperiod did not favor the embryogenic formation. In absence of light, inflorescence explants of the cultivar Nanicão Jangada responded by several morphogenic responses. Induction of embryogenic and nonembryogenic callus, development of somatic embryos, continuity of the flower bud development or oxidation of the explants were observed in the cultures. The frequency of embryogenic response was low, with only $6 \%$ of the explants forming somatic embryos, while $23 \%$ showed the formation of embryogenic callus. Histological and morphological studies presented the formation of two types of somatic embryos: one resembling the zygotic embryo of Musa acuminata, and the other type showing more similarity to the zygotic embryo of other monocotyledonous species, indicating that in one somatic embryogenic protocol different morphological patterns can be observed. In addition to the formation of somatic embryos, continuity in the development of floral buds was frequently observed.

Key words: Musa spp., somatic embryogenesis, tissue culture, histology, morphology
\end{abstract}

\section{INTRODUÇÃO}

A bananeira (Musa spp.) situa-se entre as principais culturas produzidas nos países tropicais e subtropicais, tendo expressiva comercialização e aceitação mundial (Dhed'a et al., 1991). As cultivares triplóides e tetraplóides produzem as bananas comestíveis sendo, portanto, de grande importância comercial. Elas surgiram da hibridação natural entre duas espécies selvagens, Musa acuminata e Musa balbisiana, e foram, ao longo dos anos, domesticadas pelo homem. As cultivares comerciais, apresentam características desfavoráveis ao melhoramento convencional, como a baixa fertilidade, produzindo frutos partenocárpicos sem 
sementes, ou frutos com sementes estéreis, além de apresentarem poliploidia e baixa variabilidade genética (May et al., 1995). Isto dificulta a ampliação do cultivo nacional de bananeira de cultivares mais susceptíveis às doenças como Sigatoka Negra (Mycospharella fijiensis), fusariose (Fusarium oxysporum var. cubense), "Banana Bunchy Top Virus" (BBTV) e "Cucumber Mosaic Virus" (CMV), uma vez que o plantio fica limitado às regiões isentas destas doenças. Dessa forma, técnicas de cultura de tecidos associadas à transformação genética, constituem estratégias adicionais para programas de melhoramento genético. Técnicas de transformação genética possibilitam a introdução de genes, que apresentem características desejáveis, como resistência a doenças e outros estresses ambientais. Contudo, para que esta tecnologia possa ser aplicada, é necessário que haja um sistema de cultivo in vitro eficiente. A embriogênese somática, se eficientemente desenvolvida, pode permitir a obtenção de inúmeros propágulos a partir de um pequeno número de explantes.

Protocolos de regeneração de plântulas de Musa spp., via embriogênese somática, utilizando explantes de inflorescência funcionalmente masculina, foram relatados por Escalant et al. (1994), Navarro et al. (1997) e Côte et al. (1996), mostrando eficiência na formação de embriões somáticos e posterior conversão em plântulas. Outros autores relataram problemas morfológicos dos embriões somáticos, os quais apresentaram boa formação do meristema radicular, mas não apresentaram desenvolvimento satisfatório ou mesmo formação do meristema caulinar (Dheh'a et al., 1991; Lee et al., 1997). As características morfológicas dos embriões somáticos podem afetar a germinação e, conseqüentemente, a conversão dos embriões somáticos em plântulas (Rodriguez \& Wetzstein, 1994). Assim, o acompanhamento histológico das estruturas formadas permite uma melhor caracterização dos processos embriogênicos, identificando as possíveis falhas na formação do embrião somático.

O presente trabalho teve como objetivo a descrição das variações morfológicas de embriões somáticos obtidos a partir de inflorescências (dicásios) funcionalmente masculinas de cultivares de bananeiras brasileiras, Nanicão Jangada e Grand Nain, ambas do grupo AAA. A escolha do explante se deu pela observação de resultados positivos obtidos por outros autores (Escalant et al., 1994, Navarro et al., 1997, Côte et al., 1996). A adaptação do protocolo de Escalant et al. (1994) a uma cultivar nacional de grande importância econômica, mas pouco estudada como a cv. Nanicão Jangada, é necessária, uma vez que o genótipo exerce grande influência no processo embriogênico. Deste modo, a compreensão dos padrões morfológicos de embriões somáticos de Musa spp., utilizando-se cultivares brasileiras, poderá favorecer a embriogênese somática destas cultivares de importância nacional. 0 acompanhamento das alterações ocorridas nos explantes, bem como das características anatômicas dos embriões somáticos foi planejado, visando a caracterização e interpretação do processo embriogênico.

\section{MATERIAL E MÉTODOS}

Material Vegetal - Parte da inflorescência (dicásios) de bananeira do setor ândrico ("coração") das cultivares Nanicão Jangada e Grand Nain, ambas do grupo AAA, foi coletada logo após a formação do último dicásio (última "penca"), de plantas em plantio comercial localizado na região de Monte Alto, SP. O "coração" foi reduzido a cerca de $10 \mathrm{~cm}$ de comprimento, com a retirada de várias brácteas e dicásios, sendo submetido a assepsia em solução comercial de hipoclorito de sódio (2:1), durante 30 minutos, seguido de lavagem em água destilada esterilizada por três vezes, em câmara de fluxo laminar. Dicásios funcionalmente masculinos das posições 1 a 15 (zero correspondendo ao meristema floral) (Figuras 1a e 1b), foram isolados com o auxílio de microscópio estereoscópico e utilizados como explantes para indução de embriogênese somática. Os dicásios eram compostos de botões florais, tendo o dicásio da posição 15 , aproximadamente, $5 \mathrm{~mm}$ de comprimento.

Indução de embriogênese somática - As inflorescências foram inoculadas em placas de Petri $(60 \times 15 \mathrm{~mm})$ contendo meio MI, composto de sais e vitaminas de MS (Murashige \& Skoog, 1962), suplementado com $1 \mathrm{mg} \mathrm{L}^{-1}$ de ácido indolacético (IAA), $4 \mathrm{mg} \mathrm{L}^{-1}$ de ácido 2,4-diclorofenoxiacético (2,4-D), $1 \mathrm{mg} \mathrm{L}^{-1}$ de ácido naftaleno acético (NAA), $30 \mathrm{~g} \mathrm{~L}^{-1}$ de sacarose e solidificado com $7 \mathrm{~g} \mathrm{~L}^{-1}$ de ágar, conforme Escalant et al. (1994). Foram realizados experimentos de indução em condição de cultura com ausência de luz, e em fotoperíodo de 16 horas, sob intensidade luminosa de 4 $\mu \mathrm{mol} \mathrm{m} \mathrm{m}^{-1}$ a $27 \pm 2^{\circ} \mathrm{C}$ (TABELA 1), utilizando-se as cultivares Grand Nain e Nanicão Jangada. No entanto, optou-se, posteriormente, pela indução e manutenção das culturas no escuro, devido à grande oxidação dos explantes induzidos no claro, utilizando-se explantes somente da cultivar Nanicão Jangada, pela disponibilidade de material no campo. Após 3 meses em meio de indução, o material (embriões obtidos e os explantes) foi transferido para meio de germinação MG, o qual consiste de sais de MS, vitaminas de Morel, $30 \mathrm{~g} \mathrm{~L}^{-1}$ de sacarose, solidificado com $2 \mathrm{~g} \mathrm{~L}^{-1}$ de phytagel e suplementado com $0,05 \mathrm{mg} \mathrm{L}^{-1}$ de benzilaminopurina (BAP) e $0,2 \mathrm{mg} \mathrm{L}^{-1}$ de IAA, conforme Escalant et al. (1994). O pH do meio foi ajustado para $5,8 \mathrm{com} \mathrm{KOH}$ $(1 \mathrm{~N})$ antes da autoclavagem a $121^{\circ} \mathrm{C}$ por $20 \mathrm{~min}$.

Análise Histológica - Coletaram-se amostras dos explantes com zero dias, e após dois meses no meio MG. As amostras foram fixadas por um período mínimo de 8 horas em solução de paraformaldeído $(3 \%, p / v)$ e 
glutaraldeído $(2 \%, v / v)$ em cacodilato de sódio $0,2 \mathrm{M}, \mathrm{pH}$ 7,2 (Rodriguez \& Wetzstein, 1998), sob refrigeração, sendo a primeira hora sob vácuo. Os tecidos fixados foram lentamente desidratados à temperatura ambiente em uma série crescente de etanol (35 a 100\%), seguido de imersão em solução de etanol (100\%):meio de infiltração (1:1) durante 12 horas, a $4^{\circ} \mathrm{C}$. Em seguida, as amostras foram transferidas para meio de infiltração por $24 \mathrm{~h}$, ou até que as amostras ficassem translúcidas e no fundo do recipiente, sendo mantidas a $4^{\circ} \mathrm{C}$. Para infiltração e emblocagem, utilizou-se o kit Historesina (hidroxietilmetacrilato, Leica, Heidelberg). A polimerização foi feita à temperatura ambiente por 24 a $48 \mathrm{~h}$. Cortes seriados com espessura de 3-5 $\mu \mathrm{m}$ foram realizados. Os cortes histológicos foram corados em fucsina ácida (5\%), seguida de azul de toluidina (1\%), ou somente solução de azul de toluidina (1\%) (Feder \& O'Brien, 1968).

\section{RESULTADOS E DISCUSSÃO}

Os botões florais funcionalmente masculinos de bananeira, cultivares Nanicão Jangada e Grand Nain, mantidos em fotoperíodo de 16 horas, ficaram oxidados ou esverdeados após 2 meses de cultivo (Figura 2a), apresentando intumescimento dos botões florais e não apresentando formação de calos ou estruturas embriogênicas (TABELA 2). Tal fato indica que a manutenção dos explantes nessas condições de cultura não são adequadas para a indução da embriogênese somática nestas cultivares, diferindo do relato feito por Escalant et al. (1994), que obtiveram elevada resposta embriogênica na cv. Grand Nain. Os explantes de 'Nanicão Jangada' mantidos no escuro responderam após 2 a 3 meses em meio de indução MI, formando calos embriogênicos de coloração amarelada e esbranquiçada na superfície dos botões florais (Figura $2 b)$. Nos explantes da cultivar Grand Nain porém, observou-se elevada oxidação ou formação de calos de aparência não-embriogênica, de aspecto friável e translúcido, não tendo se observado a formação de calos embriogênicos (TABELA 2). Navarro et al. (1997), obtiveram a partir de inflorescências masculinas dessa cultivar, 2 a $6 \%$ de explantes com formação de calos embriogênicos e embriões somáticos em meio de proliferação, com reduzida concentração de 2,4-D.
Escalant et al. (1994), observaram maior formação de embriões somáticos na cv. Grand Nain, grupo AAA, quando comparado com a cv. Pelipita, do grupo ABB, indicando que a capacidade embriogênica é dependente do genótipo.

$\mathrm{Na}$ cv. Nanicão Jangada, notou-se que cerca de 3 a 4 semanas após a inoculação, os explantes já apresentavam algumas alterações morfológicas, como ligeiro intumescimento dos botões florais e alteração da coloração de branca para amarelada.

Após 3 meses em meio Ml, os explantes que apresentaram alterações morfológicas foram transferidos para meio MG, permanecendo por mais 3 meses. Durante os seis meses de cultivo, diversas alterações foram observadas nos explantes, desde oxidação, formação de calos embriogênicos ou não-embriogênicos, continuidade de desenvolvimento dos botões florais e formação de embriões somáticos.

Observou-se a formação de dois tipos de embriões somáticos com características morfológicas distintas. O primeiro apresentou estrutura do tipo cogumelo, semelhante a embriões zigóticos de Musa acuminata (AA) (McGahan, 1961), e Musa balbisiana (BB) (Escalant \& Teisson, 1987). O segundo tipo apresentou morfologia mais alongada, semelhante a embriões zigóticos de outras monocotiledôneas.

Cortes histológicos dos embriões somáticos do tipo cogumelo (Figuras 2c e 2d), revelaram duas estruturas anatômicas distintas. Alguns destes embriões (Figura 2c) apresentavam uma região apical constituída pelo haustório (h) (parte principal do cotilédone), e uma região basal sede do futuro eixo embrionário. As regiões apical e basal estavam conectadas por cordões procambiais. Este tipo morfológico, apresenta

TABELA 1 - Total de explantes em cada experimento para indução de embriogênese somática em bananeira.

\begin{tabular}{lcc}
\hline Cultivar & No. de dicásios & $\begin{array}{c}\text { Condição de } \\
\text { cultura }\end{array}$ \\
\hline Grand Nain & 105 & 16 h de luz \\
Nanicão Jangada & 150 & Escuro \\
& 150 & 16 h de luz \\
& 720 & Escuro \\
\hline
\end{tabular}

TABELA 2 - Alterações observadas em explantes de cultivares de bananeira, sob diferentes condições de cultivo.

\begin{tabular}{lcccccc}
\hline \multirow{2}{*}{ Cultivar } & \multirow{2}{*}{ Condição de cultura } & \multirow{2}{*}{ Meio de Cultura } & \multicolumn{4}{c}{ Alteração observada no explante $(\%)$} \\
\cline { 4 - 7 } & & & $\mathrm{E}$ & $\mathrm{CE}$ & $\mathrm{CNE}$ & $\mathrm{O}$ \\
\hline Grand Nain & $16 \mathrm{~h}$ de luz & $\mathrm{Ml}$ & 0 & 0 & 0 & 100 \\
Grand Nain & Escuro & $\mathrm{Ml}$ & 0 & 0 & 28 & 72 \\
Nanicão Jangada & $16 \mathrm{~h}$ de luz & $\mathrm{Ml}$ & 0 & 0 & 0 & 100 \\
Nanicão Jangada & Escuro & Ml e MG & 6 & 23 & 39 & 32 \\
\hline
\end{tabular}

CE: calos embriogênicos; CNE: calos não embriogênicos; E: formação de embrião; O: explante oxidado ou esverdeado; MI: meio de indução; MG: meio de germinação. 

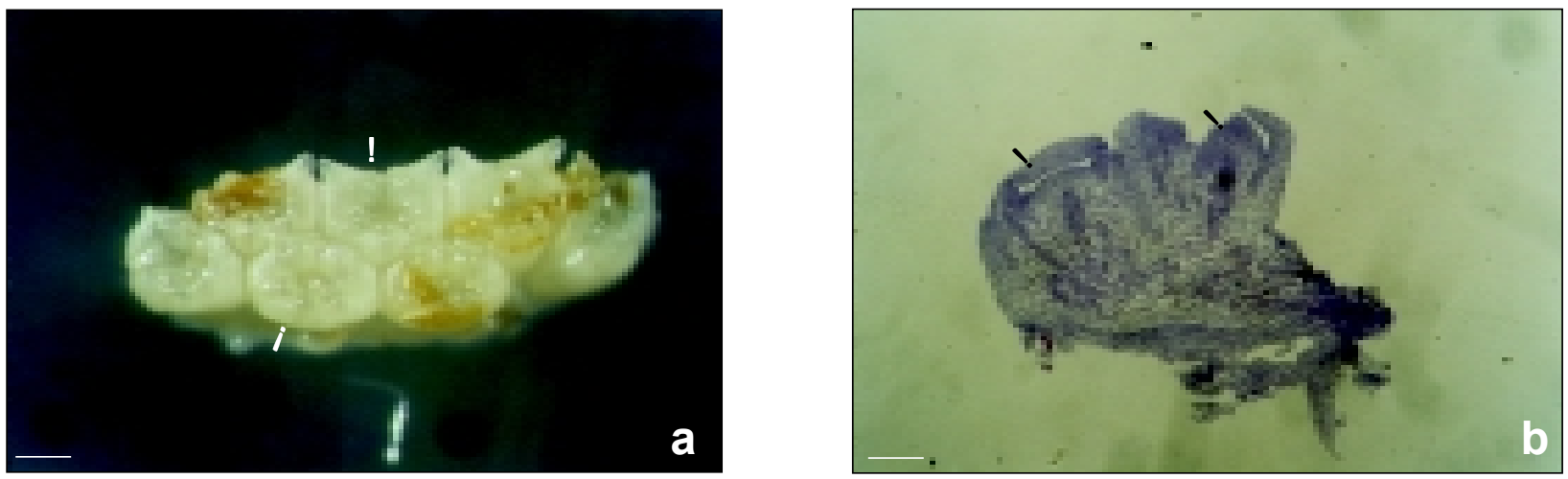

Figura 1 - Explante utilizado para indução de embriogênese somática em bananeira. a) dicásio obtido da região ândrica, com sete botões florais (pontas de seta); b) seção longitudinal da inflorescência, com botões florais (pontas de seta). Barras $=200 \mu \mathrm{m}$.
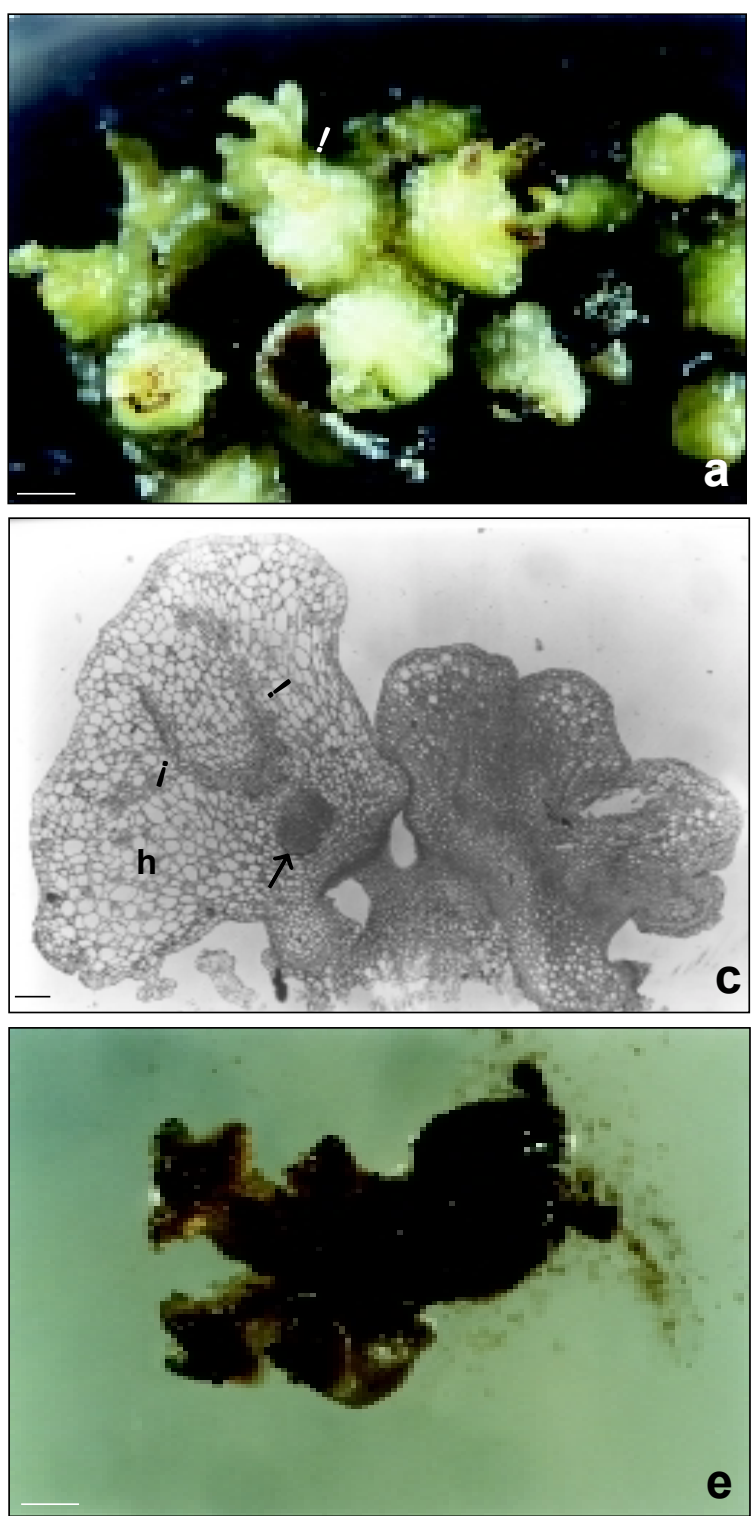
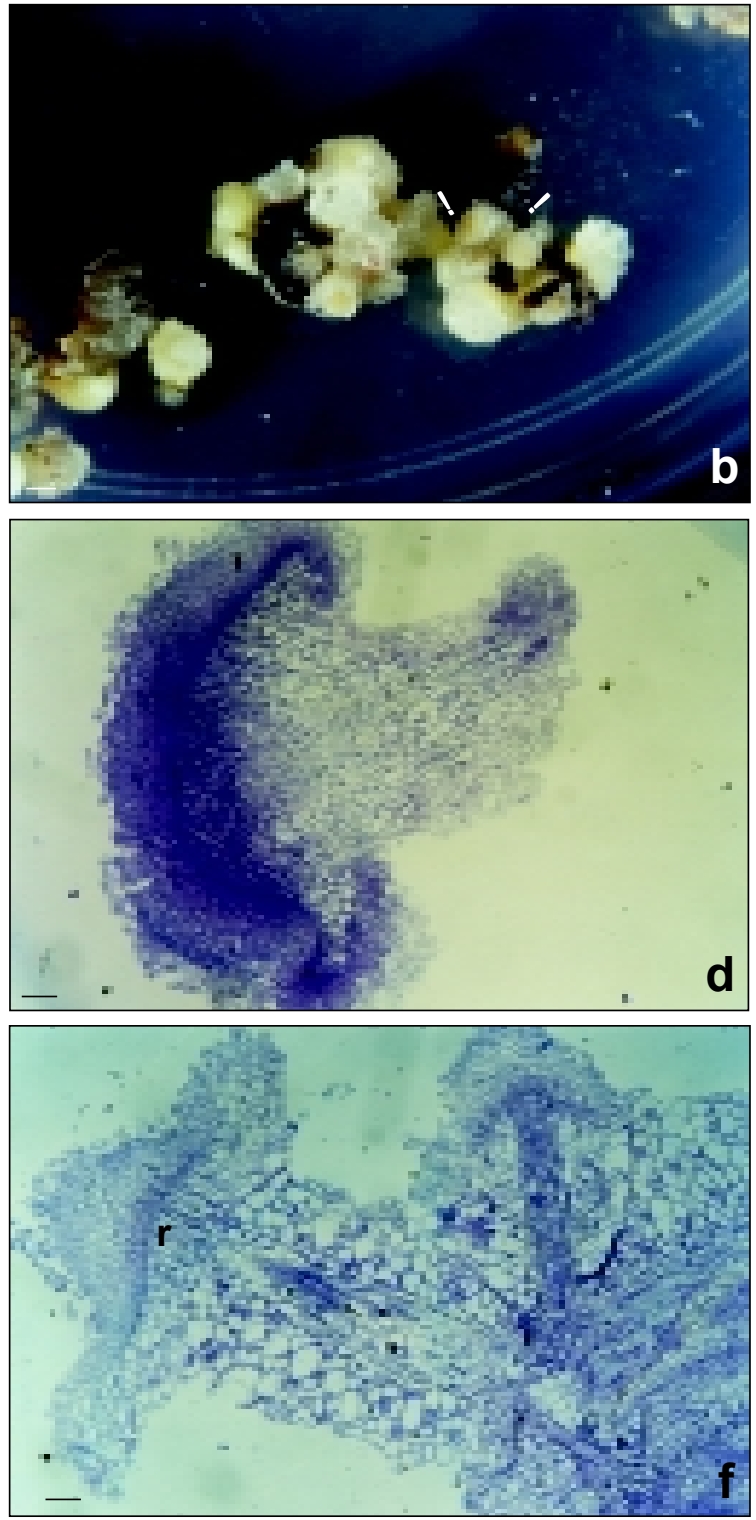

Figura 2 - Cultivo in vitro de dicásios de bananeira, cv. Nanicão Jangada. a) explantes com intumescimento dos botões florais (ponta de seta), coloração esverdeada dos tecidos e ausência de formação de calo; b) calos embriogênicos e embriões somáticos (ponta de seta); c-d) seção longitudinal dos embriões somáticos do tipo cogumelo c) eixo embrionário (seta) e cordões procambiais (pontas de seta) na região do haustório (h); d) embrião somático com ausência de formação dos meristemas apicais, procâmbio e protoderme; e) estruturas semelhantes a raízes; f) seção longitudinal das estruturas da figura 2e, com meristema apical radicular (r) e a conexão vascular com o tecido do explante. Barras $=1 \mathrm{~mm}(a, b, e) ; 200 \mu \mathrm{m}(c, d, f)$. 

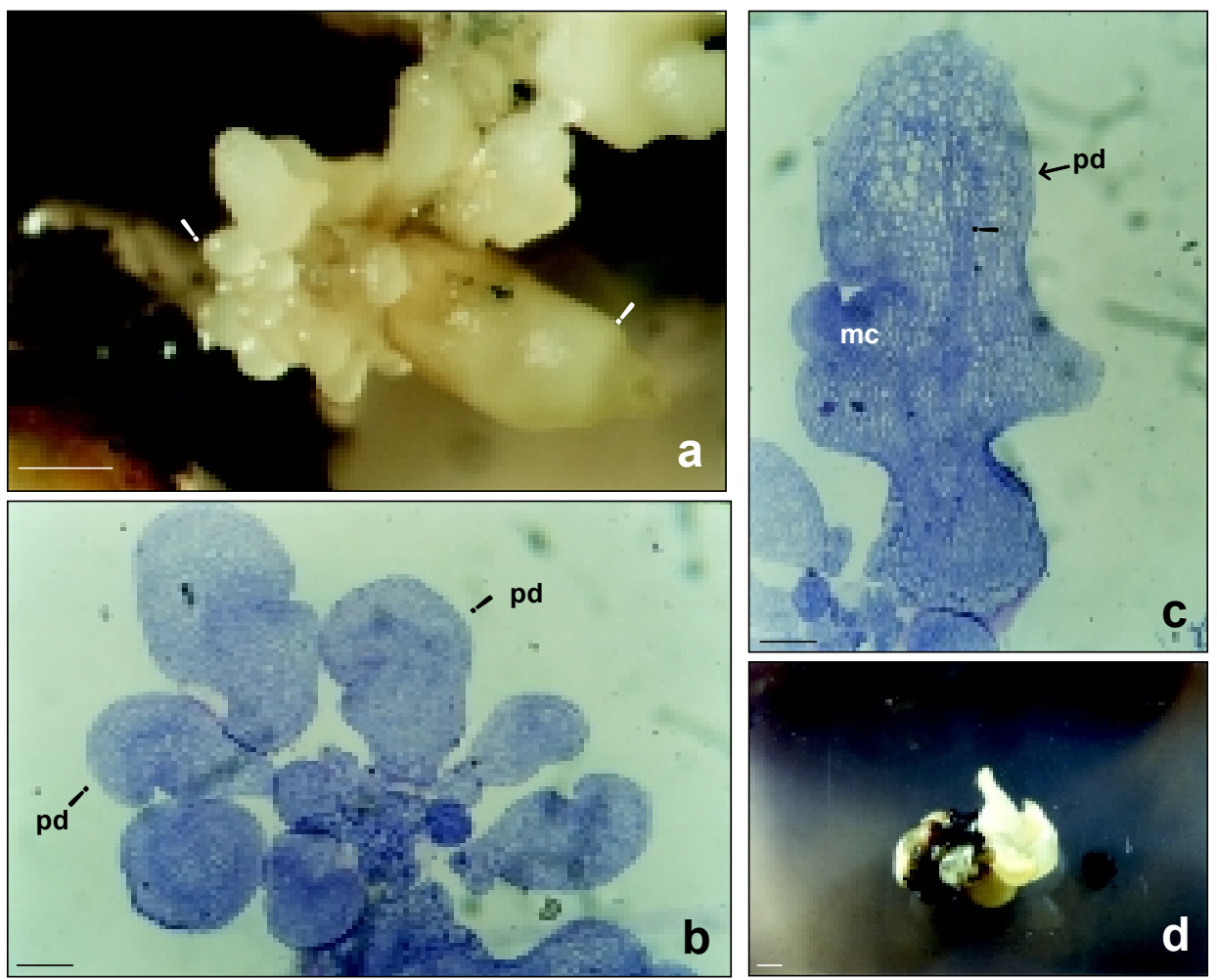

Figura 3 - Embriões somáticos de bananeira, cv. Nanicão Jangada. a) embriões somáticos (pontas de seta), em diversos estágios de desenvolvimento; b) cortes histológicos de embriões somáticos, mostrando protoderme bem definida (pd); c) seção longitudinal de embrião somático bem desenvolvido, mostrando a protoderme (pd), faixa procambial (ponta de seta) e o meristema caulinar (mc); d) Botão floral desenvolvido em meio MI. Barra = $1 \mu \mathrm{m}(\mathrm{a}-\mathrm{d},) ; 100 \mu \mathrm{m}(\mathrm{b}-\mathrm{c})$;
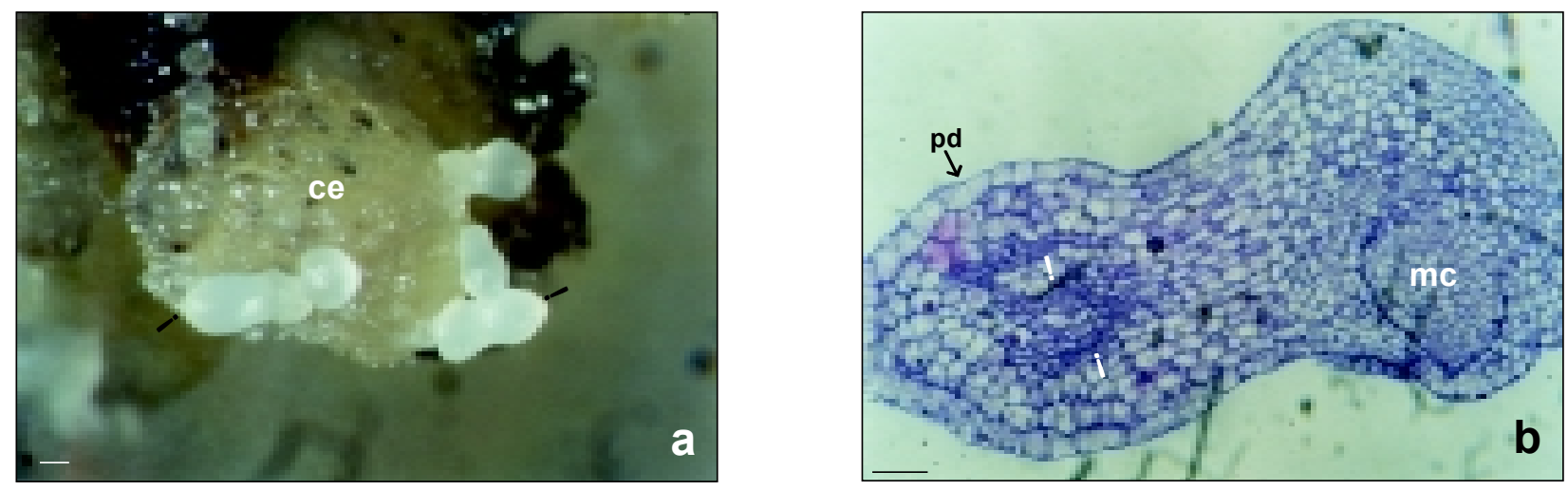

Figura 4 - Embriões somáticos de Musa spp. cv. Nanicão Jangada. a) embriões somáticos (pontas de seta) formados a partir de calo embriogênico (ce); b) seção longitudinal do embrião somático evidenciando o início de formação do procâmbio (pontas de seta), meristema caulinar (mc) e protoderme (pd) bem definida. Barras $=200 \mu \mathrm{m}(\mathrm{a}) ; 100 \mu \mathrm{m}(\mathrm{b})$.

características anatômicas semelhantes aos embriões zigóticos das espécies selvagens de Musa (McGahan, 1961). Variações desta estrutura anatômica apresentavam coloração amarelada e que se destacavam facilmente dos explantes, revelando porém, ausência de diferenciação dos meristemas apicais, do procâmbio e de uma protoderme definida (Figura $2 \mathrm{~d}$ ). Também observaram-se, em alguns casos, o surgimento de estruturas monopolares, com conexão vascular com o tecido do explante, indicando a formação de raízes ( $r$ ) (Figuras 2e e 2f).
Em menor frequência, verificou-se na superfície dos explantes o segundo tipo morfológico de embriões somáticos, mais alongados, apresentando uma chanfradura lateral, onde se localiza o meristema caulinar (Figuras 3a, 3c e 4a,4b), assemelhando-se a embriões zigóticos de outras monocotiledôneas. Através de análise histológica dessas estruturas formadas na base do botão floral (Figura 3a), identificaram-se embriões somáticos em diferentes fases de desenvolvimento (Figuras $3 \mathrm{~b}$ e 3c) apresentando, uma protoderme definida caracterizada por uma camada de células justapostas. 
No embrião mais desenvolvido (Figura 3c), observaramse as faixas procambiais e o meristema caulinar. Este tipo de embrião somático assemelha-se àqueles obtidos por Escalant et al. (1994) e Navarro et. al. (1997).

Embriões com formato ligeiramente mais arredondados (Figuras $4 \mathrm{a}$ e $4 \mathrm{~b}$ ), foram também observados. Cortes histológicos seriados mostraram que esses embriões apresentavam protoderme definida (Figura 4b), início de formação de uma região procambial e uma chanfradura lateral, com início de diferenciação do meristema caulinar. Cronauer-Mitra \& Krikorian (1988), também observaram esse tipo de embrião, originário do cultivo in vitro de embriões zigóticos de uma espécie ornamental, Musa ornata Roxb.

Em vários explantes em meio de indução, foi também observado o desenvolvimento dos botões florais. Pelas características morfológicas, essas estruturas podem ser confundidas com embriões somáticos iniciando o processo de germinação (Figura 3d).

A transferência dos embriões somáticos para meio de germinação $M G$, independente do tipo morfológico, não proporcionou o desenvolvimento dos mesmos, observando-se somente oxidação gradual, não tendo sido possível a conversão de embriões em plantas, nas condições de cultivo testadas.

Nos trabalhos envolvendo a embriogênese somática em Musa spp., não há relatos de diferenças morfológicas entre os embriões somáticos produzidos sob as mesmas condições de cultivo (Marroquin et al., 1993; Banerjee et al., 1987; Cronauer-Mitra \& Krikorian, 1988). Megia et al., (1993) e Lee et al. (1997), obtiveram embriões somáticos com características morfológicas semelhantes aos embriões zigóticos de Musa acuminata, enquanto que Cronauer-Mitra \& Krikorian (1988), Escalant et al. (1994) e Navarro et al. (1997) obtiveram embriões somáticos com morfologia alongada. Apesar desses resultados, a presença de diferentes formas de embriões somáticos em uma só cultivar de Musa spp., ou em um mesmo protocolo de obtenção de embriogênese somática, não havia sido anteriormente relatada.

Em relação ao número total de explantes introduzidos da cultivar Nanicão Jangada, em condições de ausência de luz, verificou-se a formação de calos embriogênicos (23\%) ou não embriogênicos (39\%) e uma reduzida porcentagem de diferenciação de embriões somáticos (6\%) (TABELA 2).

\section{REFERÊNCIAS BIBLIOGRÁFICAS}

BANERJEE, N.; SCHOOFS, J.; HOLLEVOET, S.; DUMORTIER, F.; DE LANGHE, E. Aspects and prospects of somatic embryogenesis in Musa, ABB, cv. Bluoggoe. Acta Horticulturae, n.212, p.727-730, 1987.

CÔTE F.X.; DOMERGUE, R.; MONMARSON, S.; SCHWENDIMAN, J.; TEISSON, C.; ESCALANT, J.V. Embryogenic cell suspensions from the male flower of Musa AAA cv. Grand Nain. Physiologia Plantarum, v.97, p.285290, 1996.
CRONAUER-MITRA, S.S.; KRIKORIAN, A.D. Plant regeneration via somatic embryogenesis in the seeded diploid banana Musa ornata Roxb. Plant Cell Reports, v.7, p.23-25, 1988.

DHED'A, D.; DUMORTIER, F.; PANIS, B.; VUYLSTEKE, D.; DE LANGHE, E. Plant regeneration in cell suspension cultures of cooking banana cv. Bluggoe (ABB group). Fruits, v.46, p.125135, 1991.

ESCALANT, J.V.; TEISSON, C. Comportements in vitro de l'embryon isolé du bananier (Musa species). Fruits, v.42, p.333-342, 1987.

ESCALANT, J.V.; TEISSON, C.; CÔTE, F. Amplified somatic embryogenesis from male flowers of triploid banana and plantain cultivars (Musa spp.). In Vitro Cellular and Developmental Biology, v.30, p.181-186, 1994.

FEDER, N.; O'BRIEN, T.P. Plant microtechnique: some principles and new methods. American Journal of Botany, v.55, p.123142, 1968.

LEE, K.S.; ZAPATA-ARIAS, F.J.; BRUNNER, H.; AFZA, R. Histology of somatic embryo initiation and organogenesis from rhizome explants. Plant Cell, Tissue and Organ Culture, v.51, p.1-8, 1997.

MAY, G.D.; AFZA, R.; MASON, H.S.; WIECKO, A.; NOVAK, F.J.; ARNTZEN, C.J. Generation of transgenic banana (Musa acuminata) plants via Agrobacterium-mediated transformation. Bio/Technology, v.13, p.486-492, 1995.

MARROQUIN, C.G.; PADUSCHECK, C.; ESCALANT, J.V.; TEISSON, C. Somatic embryogenesis and plant regeneration through cell suspensions in Musa acuminata. In Vitro Cellular and Developmental Biology-Plant, v.29, p.43-46, 1993.

MEGIA, R.; HAÏCOUR, R.; TIZROUTINE, S.; BUI TRANG, V.; ROSSIGNOL, L.; SIHACHAAKR, D.; SCHWENDIMAN, J. Plant regeneration from cultured protoplasts of the cooking banana cv. Bluggoe (Musa spp., ABB group). Plant Cell Reports, v.13, p.41-44, 1993.

McGAHAN, M.W. Studies on the seed of banana: I. Anatomy of the seed and embryo of Musa balbisiana. American Journal of Botany, v.48, p.230-238, 1961.

MURASHIGE, T.; SKOOG, F. A revised medium for rapid growth and bioassays with tobacco tissue cultures. Physiologia Plantarum, v.15, p.473-497, 1962.

NAVARRO, C.; ESCOBEDO, R.M.; MAYO, A. In vitro plant regeneration from embryogenic cultures of a diploid and a triploid, Cavendish banana. Plant Cell, Tissue and Organ Culture, v.51, p.17-25, 1997.

RODRIGUEZ, A.P.M.; WETZSTEIN, H.Y. The effect of auxin type and concentration on pecan (Carya illinoinensis) somatic embryo morphology and subsequent conversion into plants. Plant Cell Reports, v.13, p.607-611, 1994.

RODRIGUEZ, A.P.M.; WETZSTEIN, H.Y. A morphological and histological comparison of the initiation and development of pecan (Carya illinoinensis) somatic embryogenic cultures induced with naphthaleneacetic acid or 2,4dichlorophenoxyacetic acid. Protoplasma, v.204, p.71-83, 1998.

\footnotetext{
$\overline{\text { Recebido em } 30.08 .00}$
} 